\title{
The Contribution of Ethics to Banking Governance: An Analysis in Subsidiary Banks with Predominantly Pan-African Capital
}

\author{
Ongono Amogo Tobie Nicaise ${ }^{1}$, Dadem Kemgou Edouard Guilaire ${ }^{2}$, Lekini Dieudonné Justin ${ }^{3}$ \\ ${ }^{1}$ Department of Accounting and Finance, Faculty of Economics and Management, University of Dschang, Dschang, Cameroon \\ ${ }^{2}$ Department of Banking and Finance, Faculty of Economics and Management, University of Bamenda, Bamenda, Cameroon \\ ${ }^{3}$ Department of Marketing and Management, Faculty of Economics and Management, University of Dschang, Dschang, Cameroon
}

Email address:

tobieongono@yahoo.com (O. A. T. Nicaise), dadem.edouard@yahoo.fr (D. K. E. Guilaire), Justyled@yahoo.fr (L. D. Justin)

\section{To cite this article:}

Ongono Amogo Tobie Nicaise, Dadem Kemgou Edouard Guilaire, Lekini Dieudonné Justin. The Contribution of Ethics to Banking Governance: An Analysis in Subsidiary Banks with Predominantly Pan-African Capital. International Journal of Accounting, Finance and Risk Management. Vol. 6, No. 2, 2021, pp. 61-68. doi: 10.11648/j.ijafrm.20210602.14

Received: November 21, 2020; Accepted: December 9, 2020; Published: June 30, 2021

\begin{abstract}
The objective of this article is to contribute to a better understanding of the contribution of ethics in banking governance. The field of investigation is Cameroon. The study covers three subsidiary banks with predominantly Pan-African capital. The empirical material results from an approach marked by documentary study and the realization of semi-structured interviews with managers and bank customers. The results of the analysis show that the banks surveyed see ethics as a governance tool that enables them to improve their image and reputation. They open a reflection on the governance model capable of promoting the consideration of ethics within the banks surveyed.
\end{abstract}

Keywords: Ethics, Banking Governance

\section{Introduction}

The financial instability that began in the United States in 2007 exposed the perverse effects of immoral banking practices on society. It crystallized reflections on the vulnerability of the banking system in the face of a crisis. From a domino effect, a banking crisis can spread to other banks and lead to a systemic crisis [9]. Despite many measures taken to protect depositors and the banking system, the debate over ethics in banking remains alive. It refers to the orientation of bankers' decisions towards more morality. In the banking sector, the actions taken by decision-makers can be assessed according to their conformity or not with certain ethical values. Therefore, they can take on a moral or an immoral character. The subprime crisis illustrated this by highlighting the immoral practices of bankers. Through a securitization logic which consisted in transforming traditionally illiquid bank loans into negotiable securities on the markets, the banks transferred their credit risk to the investors who bought them. However, the latter did not receive the income from the loans because the mortgages were granted to risky borrowers. These practices have been identified as one of the causes of the crisis and have raised the problem of bank governance.

The governance of banks is special. This particularity stems from the fact that specificities such as: informational asymmetry, the level of indebtedness and the strong regulation make the governance of banks different from that of non-financial firms [22]. Although it is present in all organizations, information asymmetry is more heightened in the banking sector because banks seem more opaque than other firms [29]. The weight of banking regulations is justified by the desire to protect savers and the banking system against the risks of bankruptcy. As the role of the bank is to transform deposits into loans by having poor information on the quality of bank assets, this results in a loss of confidence and depositors can race to the counters. Due to the immediate unavailability of liquidity due to the loans granted, a considerable withdrawal of deposits can bankrupt the banking system [10].

This was illustrated during the systemic crisis that hit African countries in the 1980s. In Africa in general and Cameroon in particular, numerous ethical scandals continue to 
plague the governance of banks. By way of illustration, we can cite many cases such as that of the International Bank of Cameroon for Savings and Credit (BICEC) where the Mazars audit firm discovered embezzlement due to overbilling and invoices fictitious. The Commercial Bank of Cameroon (CBC) affair where the Central African Banking Commission (COBAC) highlighted management discrepancies, including misappropriation of capital attributed to the majority shareholder.

These scandals, which are not only attributable to African countries, lead us to ask the following question: what is the contribution of ethics to banking governance? The aim of this article is to understand the contribution of ethics to the governance of banks. To carry out our reflection, this paper is structured around three points. The first concerns the literature review. The second highlights our methodological approach. The third presents and discusses our results.

\section{Theoretical Framework and Research Proposal}

This section is devoted to a theoretical but not exhaustive examination of the concepts of ethics and banking governance. The formulation of our research proposal stems from the analysis of our theoretical framework.

\subsection{The Controversy over the Introduction of Ethics in Banking}

Ethics comes from the Greek word ethikos which means moral. It developed in the United States at the end of the 1950s It is defined as "a field of tension between the interests of the company, the general interest and the interests of others" [25]. There are a variety of definitions and they complement each other. It can be seen as a philosophy, a science, a theory, and a guide. It refers to the set of rules, codes or principles that channel the behavior of individuals or decision-makers towards greater morality. It is based on an individual disposition to act. Ethics are more individual and correspond to "Behavior whose criteria are determined by the individual himself" [4].

The debate fueling management ethics revolves around two contradictory theories. These are shareholder value theory and normative stakeholder theory. According to the shareholder theory held by Friedman M. the company has genuine moral obligations only to the shareholders [16]. Proponents of this theory argue that the company should focus on maximizing shareholder profit while complying with laws and regulations. They argue that talking about ethics beyond maximizing shareholder profits is bad. When the company respects its responsibility to shareholders, it does not have to expand that responsibility [16]. The concept of ethics is in contradiction with the considerations of neoclassical economists such as: free competition, individual initiative, total confidence in market mechanisms. According to this vision, the company must focus on maximizing shareholder profit at the expense of other moral and ethical values.
In contrast to this theory, the normative theory of stakeholders has developed. It deconstructs the shareholder theory of value and draws its roots from the work of Dodd in 1932 and Bernard in 1938. It promotes the idea that taking into account the interests of the company's partners lead to beneficial cooperation between the different actors of the organization. In 1963, the concept of stakeholder appeared clearly for the first time in a paper presented to the Stanford Research Institute. The seminal work of this theory was published by Freeman R. and is entitled "strategic management: a stakeholder approach"[13]. According to the author, a stakeholder can be understood as any collective or actor likely to influence or be influenced by the activities and externalities of the organization [15].

Stakeholder theory also called stakeholder theory provides answers to the following questions: Who is important for a company? Who are the players to whom companies should pay particular attention? In this perspective Mitchell A. and Wood D. placed the company at the heart of a set of interactions with different actors"[26]. The latter are no longer only the shareholders, but also the other stakeholders of the company, namely: employees, consumers, society or even the environment... Mitchell A. and Wood D confer on each stakeholder one or more attributes in particular: power, legitimacy and / or urgency [26]. The influence that a stakeholder exerts on the firm depends on the combination of these attributes. The stakeholders receiving the most attention are those called "final". They combine legitimacy, power and urgency. To this end, they can influence the behavior of a company.

In stakeholder theory, ethics occupies a central place and managers must demonstrate their performance beyond the economic aspect to include social and environmental aspects [28]. In this vision, ethics becomes a tool of competitiveness and differentiation within the meaning of the work of because in a competitive environment, it is a key to survival and sustainability [25].

Despite the favorable response to this theory in the abundant literature, it harbors many criticisms. The very notion of stakeholder does not seem to be unanimous among all researchers using this expression. In the end, everyone could consider themselves as a stakeholder, since "anyone could claim an interest in an organization"[17]. This difficulty in grasping with precision the very concept of stakeholder makes it difficult for managers to implement it. In addition, how can we ensure the integration of all stakeholders? Even if that would be possible, how to manage their divergent interests? [6].

In the banking sector, several dysfunctions are at the origin of the crises. Many financial scandals mar the governance of banks. The illustration can be drawn from the bankruptcy of Enron, which concealed a debt of one to two billion dollars by inflating the value of the shares. Many other scandals such as: The Madoff affair, the Kerviel affair have put the need for ethics in banking back on the agenda. It is no longer enough to trust the market. Since the actions that are taken in the banking sector are not mechanical or technical, it is important for the 
agents who intervene there to adopt an ethical posture by being concerned about the consequences of their actions on society. Given the specificities of the banking sector, appropriate governance is essential.

\subsection{The Particularities of Banking Governance: An Ethical Requirement}

Corporate governance originates from the Greek word "Kubermân" or the Latin word "goubernance". These two concepts mean directing the ship. In the Anglo-Saxon conception, governance refers to the distribution of power. The work entitled "The nature of the firm" published by Coase R. sees it as a device set up by a company in order to ensure more effective modes of coordination than the market [8]. In the early 1990s, Williamson O. E. mentioned it in the relations between shareholders and managers [35]. Corporate governance emerged in the United States at the start of the 20th century. The shift from the entrepreneurial firm to the managerial one is at the origin of the debate on corporate governance.

The corporate governance debate emerges from the separation between ownership and control. In their work entitled "The modern corporation and private property", Berles A. and Means G. put the problem of the ownership / control separation at the center of their concerns [4]. According to these authors, corporate governance stems from the birth of a new form of organization called the managerial firm. Subsequently, Jensen M. and Meckling W. further enrich the debate [19]. They show that the delegation of the power of use by the owner to the manager gives rise to a contractual relationship. The latter forces the leader to create value for the shareholder.

However, each contracting party seeks to maximize its utility function and agency conflicts arise. They are cost drivers called agency costs [14]. In order to minimize them, governance mechanisms are put in place by the shareholders. They aim to reduce the opportunism of the leader and are internal and external [7].

In the banking sector, the financial crisis of the $2000 \mathrm{~s}$ highlighted the limits of the Basel regulatory framework. As a result, the Basel committee decided to remedy the weaknesses observed by strengthening the governance mechanisms. It is with this in mind that the Basel III system was created in 2010. It aims to establish good banking governance through the establishment of new prudential standards. The examination of these standards reveals the desire of the Basel authorities to impose respect for ethics in finance. Acts in the banking sector are human matters. Therefore, if they are unethical, banking activity can only be unstable with negative consequences for the economy and society.

Given specificities such as: opacity, informational asymmetry, the level of indebtedness and strong regulation, the governance of banks appears to be specific and different from that of non-financial firms [22]. Opacity is the inability of external participants to control the behavior of interns. It amplifies agency problems within banks as shareholders find it difficult to control the activities and decisions of the management team. In addition, creditors / depositors cannot control the risk taken by shareholders and managers. Banks have information on the loans granted and this information is sometimes inaccessible and often escapes all surveillance and market discipline.

In his work entitled "The market for Lemons" Akerlof G. highlights a situation of asymmetries of information on the market [1]. The market studied is that of used vehicles. In the latter, sellers have additional information than buyers about the quality of the products and are motivated to trick buyers into selling them a bad car at the price of a good one. In such a configuration, those who own a vehicle in poor condition will try to part with it by giving it away. It is therefore complex for the buyer to make a choice between sellers who have good reasons to give up their car and those who want to because their car is already of poor quality. Faced with the risk of making the wrong choice, buyers withdraw from the market. As a result, the price of all cars goes down. Subsequently, sellers of good quality cars who consider the price too low refuse to sell their vehicle and the number of poor quality vehicles increases and even exceeds that of good quality. The wrong vehicles end up throwing out the good ones. This model illustrates a market failure that is dragging the economy down.

Stiglitz j. and Weiss A. transpose [1] model to the credit market [31]. For these authors, uncertainty stems from the existence of information asymmetries between lender and borrower. Because of these asymmetries and the link between interest rate and credit quality, it is not possible to regulate the market by changing the interest rate but only by rationing credit. Information asymmetry, on the other hand, describes a situation of imperfect information. It highlights a situation in which one of the parties to a transaction, in this case the borrower in the banking sector is better informed about his own quality or that of his project than the bank [31]. Although it is present in all forms of business, it is more supported in banking firms because banks are more opaque than other firms. The reason for this finding lies in the quality of the loans. These are difficult to control and are likely to be camouflaged. Only the bank has the exact information on the credit risk it grants.

As for the level of indebtedness of banks, it is explained by a particular configuration of their balance sheets. The latter differs from that of nonfinancial corporations because about $90 \%$ of bank assets are financed by customer deposits [23]. Liabilities, on the other hand, consist mainly of clients' savings which can be called upon by them at any time [23]. The role of the bank being the transformation of deposits into loans by having bad information on the quality of bank assets, depositors can proceed with the massive withdrawal of their savings [10]. The race for the counters that can result from this materializes their loss of confidence in the banking system. When the bank's clients are under suspicion and they demand all of their savings, due to the immediate unavailability of liquidity, a systemic crisis can arise.

Given the domino effect, cascading bank failures can lead to a financial crisis, the externalities of which can be 
detrimental to the economic development of several countries. To prevent these slippages Diamond D. W. and Dybvig P. recommend setting up a deposit guarantee scheme called prudential regulation in order to protect savers and the banking system [10]. This is micro-prudential and macro-prudential regulation. In view of the specificities of banking activity, it becomes relevant to show how the introduction of ethics in the governance of banks can contribute both to the protection of depositors and to the stability of the banking system.

\subsection{Prudential Standards: A Desire to Establish Ethics in Banking}

The debate on the stability of the banking system has arisen since the 1970s following the banking crises. To curb the harmful effects of crises on the economy, the first mechanism put in place to regulate banking activity in the United States was the "gearing ratio". It forced banks to hold a certain level of capital for a given loan. The banking crisis being the consequence of an illustration of the immoral practices of banks, this regulatory device carried with it the seeds of ethics because it aimed to make the practices of bank managers moral.

At the beginning of the 1980 s, the fall in the level of capital of the main international banks as well as the rise of ethical risks led the members of the Basel Committee to institute in 1988 an international agreement whose objective was to strengthen the stability of the system. international banking. This agreement called Basel I led to the introduction of the so-called Cooke ratio. The latter aimed to cover credit and liquidity risk based on a capital requirement to be included in the calculation of financial costs, which represents $8 \%$ of risky loans granted.

The ambition of this ratio being to increase the solidity and stability of the international banking system, we can perceive in it a desire on the part of the members of the Basel Committee to institute moral practices within banks in order to reframe the decisions of bank executives. However, the Cooke ratio revealed many limits due to the immoral practices of banks. The trend towards regulatory arbitrage has compromised the effectiveness of the Cooke ratio [3]. Faced with the limits of this ratio, the Basel committee has implemented a new system called Basel II.

The ratio that emerged following Basel II in 2006 is called the Mc Donough ratio. He wants to be more flexible and sensitive. It aims to channel the behavior of banks through ethical practices in order to stabilize the banking system. As a result, it constitutes the basis of new prudential regulations in order to protect depositors and the banking system. Among the innovations introduced by this new system, we note the obligation of banks to regularly disseminate information on their activity. This once again reflects a desire to promote ethical practices within banks. However, despite the measures taken to reframe the behavior of actors through moral practices, from the subprime crisis of the 2000s, new immoral practices have been identified which have called into question the ability of the $\mathrm{Mc}$ Donough ratio to manage non-compliance. only the individual risk but also the systemic risk.

Faced with the disastrous consequences of the last financial crisis, the Basel Committee undertook new reforms through the Basel III system in 2010. It is based on the capital requirement in order to guarantee the solvency of banks. It reinforces the banks' resistance by raising the minimum equity ratio from $8 \%$ to $10 \%$. This measure requires banks to hold a level of equity proportional to the risk incurred. The objective of the Basel Committee being to provide responses to remedy the immoral practices at the origin of the crisis, the measures adopted resulted in three waves of reforms, in particular: Capital Requirements Directive II, Capital Requirements Directive III and Capital Requirements Directive IV. All of these reforms aim to make the players in the banking system accountable and promote a certain ethic.

The evolution of international prudential standards (Basel I-Basel III) shows the growing desire of regulatory authorities to reframe the responsibility of the banking system in the event of a crisis. At the heart of the measures adopted to prevent possible bank failures, we note compliance with prudential rules which, in our opinion, reflect a desire to consolidate ethics in banking. The above developments underpin our following research proposal: ethics can be understood as a tool of banking governance.

\section{Our Empirical Research Protocol}

Our study aims to understand the contribution of ethics in the governance of banks. To carry out our reflection, we have adopted an essentially qualitative approach. This required semi-structured interviews with managers and bank customers. The solicitation of bank managers, in this case branch heads, is justified by the fact that they are the actors who implement the ethics policy of the banks surveyed on a daily basis. The attention paid to customers is explained by the fact that they are the actors who live the ethical policy driven by the banks interviewed on a daily basis.

Our research protocol mobilizes ingrained theory which "is characterized by the desire to update the perspectives of meaning that a person or a group of people gives to their experience» [12]. This is to highlight the intelligence of the above-mentioned actors. Our experimentation area is Cameroon. The sample to which our investigation relates concerns three (03) subsidiary banks with majority Pan-African capital. For reasons of anonymity, these three (03) subsidiary banks are coded in FBP1; FBP2 and FBP3. These subsidiary banks have their general management in the city of Douala. The examination of the banks surveyed follows a logic of triangulation. This allowed us to highlight different techniques in order to collect data on the same phenomenon. It is with this in mind that we used the activity reports published by the banks surveyed as well as semi-structured interviews with managers and bank customers.

The activity reports informed us about the ethical themes developed by each bank surveyed. Not having enough empirical information on ethics in banking, it seemed relevant 
to us to talk to the above-mentioned players. As Blanchet A. and Gotman A. affirm: "The interview is necessary whenever we ignore the world of reference, or when we do not want to decide a priori on the system of reference. Internal consistency of the information sought (...). The purpose of the interviews is to highlight the aspects of the phenomenon which the researcher cannot think of spontaneously and to complete the avenues of work suggested by his readings" [5]. It is in this interpretive approach that we conducted the semi-structured interviews in the cities of Yaoundé (political capital of Cameroon) and Douala (economic capital of Cameroon) between May and June 2020. They were oriented towards nine (09) branch managers and twenty (20) bank clients.

We have mobilized various channels for access to requested bank managers. In this case, this is email; telephone contact; of the exploitation of our social capital in terms of friends and of our user status in certain banks. The interview requests were sent to nine (09) subsidiary banks but in the end three (03) of them gave favorable opinions to our study. The six (06) others issued unfavorable opinions without however explaining the reasons for the refusal. Numerous reminders were necessary since the interviewees face many occupations relating to their daily work. An interview guide was made available to each interviewee.

When contact was established, we explained to respondents the relevance of our study and guaranteed them the confidentiality and anonymity of their answers or statements. This phase of the survey was decisive as it helped to build a climate of trust so that respondents could express themselves freely in conversations [20]. Interviews lasted an average of 25 minutes and were recorded. Most of these were carried out outside the bank. The main topics discussed during the exchange concerned the ethical practices of the banks surveyed. Tables 1 and 2 illustrate the content of our interview guides.

Table 1. Interview guide for agency heads.

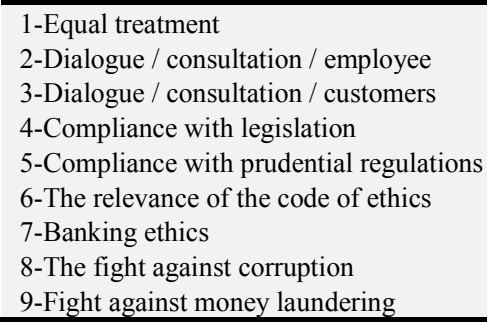

Source: The author

Table 2. Interview guide for bank customers.

1-Taking complaints into account

2-Consideration of suggestions

3 -Access to credit

4-Respect for customers

5-Corruption

6-Bank-customer exchange forums

7- Satisfaction with the bank

Source: The author

In order not to embarrass the respondents, we started with broad and comprehensive questions. The aim was to establish connivance so that they could express themselves freely. As Huberman A. and Miles, M advise, the investigator must first break the ice with broad-based questions [18]. Thereafter, he must move on to questions that really interest him. Each of these interviews was not very structured but oriented towards the thematic axes identified in the literature and social reports. At the end of our interviews, we have reached theoretical saturation. It is understood as the level of investigation where additional information appears to be redundant and no longer participates in the characterization of the properties of each group. As Thietart R. specifies, it is when the marginal case no longer provides additional information or new facts that the saturation point is reached [32].

The analysis of the data collected required a coding phase which allowed us to tackle the thematic content analysis. The aim is to report on what the interviewees said. Following the recommendations of Huberman A. and Miles, $M$. the interviews, all recorded as we have already mentioned, were transcribed in order to constitute the verbatim on which our interpretation focused [18]. From the verbatim, an analysis grid was designed. The latter revealed the identity of the bank according to the interviewee, the function performed by each respondent and the characteristic of the bank-subsidiary according to its capital structure. The interpretation of our data shows the validity of our research proposal, namely: ethics can be understood as a tool of banking governance.

\section{The Presentation and Discussion of Our Results}

The structure of the share capital allowed us to differentiate the subsidiary banks surveyed (FBP1; FBP2 and FBP3). The selection criterion retained for each subsidiary bank in our study is the percentage of capital held by the majority shareholder. Table 1 shows the structure of the share capital of the banks studied.

Table 3. Structure of the share capital of the banks studied.

\begin{tabular}{llll}
\hline Banks & $\begin{array}{l}\text { Capital held by } \\
\text { the State }\end{array}$ & $\begin{array}{l}\text { Capital held by the } \\
\text { parent company }\end{array}$ & Other \\
\hline FBP1 & $35 \%$ & $55 \%$ & $10 \%$ \\
FBP2 & $37 \%$ & $59 \%$ & $4 \%$ \\
FBP3 & $33 \%$ & $62 \%$ & $5 \%$ \\
\hline
\end{tabular}

Source: The author

From Table 1 above, we see the presence of the State in the capital of each subsidiary bank. This observation is the consequence of the vast movement to state the banks initiated during the post-independence years (1956-1970). Through institutional pressures, a new organizational adaptation was imposed on the subsidiary banks present in Africa [34]. The laws have imposed on foreign subsidiary banks the promotion of Africans to important decision-making bodies, especially with regard to the post of deputy general manager.

The coercive isomorphism Dimaggio P. and Powell W. with which the subsidiary banks have been taken is illustrated 
in Cameroon by a law which conditions each foreign subsidiary bank to cede nearly $33 \%$ of its capital to the 'State [11]. This is Ordinance 85/002 of August 31, 1985 relating to the exercise of banking activity. It stipulates that "The structure of the social capital of (banks) must show the presence of public interests (which) cannot be less than one third of the shares subscribed". The examination of the verbatim reports of branch managers and clients interviewed in terms of frequency of occurrence is highlighted in Table 4.

Table 4. The ethics policy of the banks surveyed.

\begin{tabular}{lll}
\hline Ethical themes identified & Workforce & Frequencies \\
\hline Equal treatment & 107 & 7,12 \\
Dialogue / consultation / employee & 45 & 3 \\
Dialogue / consultation / clients & 15 & 1 \\
Compliance with legislation & 183 & 12,19 \\
Compliance with prudential regulations & 243 & 16,18 \\
The relevance of the ethical code & 177 & 11,79 \\
Banking ethics & 92 & 6,12 \\
The fight against corruption & 198 & 13,19 \\
The fight against money laundering & 69 & 4,59 \\
Taking complaints into account & 32 & 2,13 \\
Consideration of suggestions & 18 & 1,19 \\
Access to credit & 195 & 13 \\
Respect for customers & 85 & 5,66 \\
Bank-customer exchange forums & 7 & 0,46 \\
Satisfaction with the bank & 35 & 2,38 \\
Total & 1501 & 100 \\
\hline
\end{tabular}

Source: author

Table 4 above illustrates the ethics policy of the subsidiary banks surveyed. Our analysis shows that the banks surveyed give priority to compliance with prudential regulations $(16.18 \%)$. This finding seems to be explained by the reforms initiated in the 1990s. To curb the effects of the systemic crisis of the 1980s in Africa, reforms were undertaken and gave rise to the creation of the Central African Banking Commission (COBAC) whose role is to ensure compliance with prudential standards.

In our opinion, this regulatory body constitutes the first ethical foundation and its mission lies in channeling the irresponsible behavior of bank managers. Addressed on this topic, the person in charge surveyed declared "All banks in Cameroon are governed by prudential standards that must be respected. For me, the first ethical foundation lies in compliance with prudential standards "[Interview with FBP1 agency manager].

Similarly, another official interviewed said: "We have an obligation to report to our supervisory authorities, COBAC, ANIF and BEAC. There are a number of procedures that we must follow. With regard to these provisions we have a responsibility towards them. I think it goes back to the ethics you are referring to "[Interview with FBP3 head of agency].

After prudential regulations, the fight against corruption $(13.19 \%)$ also occupies an important place in the ethics policy of the subsidiary banks studied. It is defined as the means through which actors vested with official power use it for personal enrichment purposes. The means used by these people are generally illegal. Corruption is an informal institution whose objective is to bypass or even compensate for the ineffectiveness of a centralized administration that is remote from local realities [33].

Corruption poses an ethical problem as it condemns immoral acts by irresponsible actors. Addressed on this topic during our interview, the interviewed manager declared: "When we know that the condition of access to credit is to give bribes to his manager, we will no longer take into account the objective factors of risk control. Yes, corruption can weaken the banking system and poses an ethical problem within our bank "[Interview with the head of the FBP2 agency]. In a similar vein, another official said: "Unfortunately, we have colleagues who trample on ethics. When you have to charge a customer for a service when the latter has already paid, this makes risk control difficult to assess. Our employees are constantly mobilized on this subject "[Interview with the head of the FBP1 agency].

Access to credit (13\%) remains mixed compared to the positions of managers and clients. The banking intermediation function makes the bank an essential agent for financing the economy. However, many issues related to access to credit place ethics at the center of discussions. Addressed on the subject the interviewed manager said: "We sell money and it's very sensitive. We need to comply not only with the regulations, but also with the customer's repayment capacity by examining the risk of non-repayment "[Interview with the head of the FBP2 agency]. These statements by the manager interviewed raise the problem of access to credit and compliance with the regulations that result from a refusal of credit. In this sense, the client interviewed said: "When you apply for a loan from the bank, there is too much hassle but since you need the money you just go with it. Otherwise, you go elsewhere. Customers are complaining" [FBP1 customer interview].

Similarly, another client interviewed said: "My bank gave me a loan but the banker didn't tell me what he was going to cut me and I think it's dangerous. There are times when they go to great lengths, they cut me the money and ignore the harm "[FBP2 client interview]. These statements from managers and bank customers interviewed show that in terms of access to credit, ethics remain mixed.

As regards equal treatment $(7.12 \%)$, it assumes an absence of discrimination. In this sense, the person in charge interviewed highlighted an absence of discrimination. From this perspective, he declared: "We advocate equal treatment within our bank. We give equal opportunities to all our employees. We are opening positions and everyone has the same chance to compete "[Head of agency FBP2].

In the same vein, another official said: "We recruit transparently and we do not encourage favors when it comes to men or women. We do not pay according to sex but in relation to competence, according to experience, according to a certain number of criteria determined by mutual agreement and which apply equally to men and women" [Head of agency FBP3]. When it comes to taking complaints into account $(2.13 \%)$, the customers surveyed recognize that they are not always taken into account. In our interview, a client said: 
"When you get to the counter you find that you have been cut the money and you start to police, this is where you are given the pros and cons. of the product subscribed" [Customer interview FBP1]. These statements from the clients interviewed raise an ethical concern because most often the actions taken by bank managers do not always correspond to ethics and the banking profession.

When we discussed the relevance of the code of ethics $(11.79 \%)$ in the banks surveyed, a manager declared: "We are in accordance with our group which has fairly well formulated and structured ethical and deontological codes" [Interview chief of FBP2 agency]. From these statements, we see that by developing an image that meets their expectations, banks improve their reputation, their image and therefore their legitimacy within the meaning of Dimaggio P. J. and Powell W. [11]. In this regard, the official surveyed said: "The brand image of the bank is very important, it is even essential.

Yes, it is absolutely important to manage the image of our bank in order to be able to develop and improve performance if not the customers do not come. "[Interview with FBP3 agency manager]. The adoption of ethical practices by the banks surveyed help propel it beyond the national framework by consolidating its legitimacy. Several empirical studies have confirmed the relationship between ethics, image and long-term profit [27]. This conclusion has also been confirmed by other researchers such as Maignan I. and Ralston D. [24]. According to these authors in the United States, ethics are understood as a marketing tool that changes conceptions of the community. This opinion is also accepted by Pesqueux Y. who perceive ethics as a device which contributes to the development of an image and a reputation [28].

\section{Conclusion and Recommendations}

Can ethics be understood as a tool of banking governance? The answer to this question has been the subject of this article. Our research protocol was based on ingrained theory. He was inspired by the work of Dione L. [12]. In this perspective, he highlighted the intelligence of the actors interviewed, in this case the branch managers and bank clients surveyed. Our results show that ethics seems to constitute a tool of banking governance because it makes it possible to channel the behavior of bank managers towards more morality in order to ensure not only the stability of the banking system but also the protection of depositors. In view of these results, it appears that ethics can be used in a disguised manner without any real practical basis. In this perspective, bank managers would seek to obtain a good image and a good reputation. However, it must go beyond this conception to be part of a dynamic based on a more concrete conception of the company. Since it remains a vague concept, the risk of recovery remains significant.

At the end of our results, we make two recommendations. The first relates to improving the regulatory and ethical framework. The top priority for bank executives is regulation when it comes to making an economic decision. Regulatory authorities should continuously monitor banking activity, sanction any financial scandal and further improve bank governance by promoting ethics. The second concerns the reflection of a governance model capable of fostering the emergence of ethics in banking.

\section{References}

[1] Akerlof G. (1970), "The market for 'lemons': qualitative uncertainty and the market mechanism," Review of Economic Studies, vol. 31, pp. 488-500.

[2] Anderson C. and Campbell T. (2004), "Corporate governance of Japanese banks", Journal of Corporate Finance, vol. 10, pp. 327-354.

[3] Artus P. (2005), "De bâle 1 à bâle 2, effets sur le marché du crédit,” Revue Economique, vol. 56, pp. 77-98.

[4] Berles A. and Means G. C. (1932), The modern corporation and private property, mac Millan, New York, 396pp.

[5] Blanchet A. and Gotman A. (1992), L'enquête et ses méthodes: l'entretien, Collection 128, Nathan, 128 pp.

[6] Capron M. and Quairel-lanoizelée F. (2007), La responsabilité sociale d'entreprise. Editions la découverte, paris.

[7] Charreaux G. and Desbrière P. (1998), "Gouvernance des entreprises: valeur partenariale contrevaleur actionnariale," Finance Contrôle Stratégie. Vol. 1, pp. 57-88.

[8] Coase R. (1937), The nature of the firm, Editions economica.

[9] Demirgüç-kunt A. and Huizinga H. (2004), "Market discipline and deposit insurance," Journal of Monetary Economics, vol. 51, pp. 375-399.

[10] Diamond D. W. and Dybvig P. H. (1986), "Banking theory, deposit insurance and bank regulation," Journal of Business, vol. 59, pp. 53-68.

[11] Dimaggio P. J. and Powell W. (1983), "The iron cage revisited: institutional isomorphism and collective rationality in organizational fields," American Sociological Review, vol. 48 , pp. $147-160$.

[12] Dione L. (2009), “Analyser et comprendre le phénomène de la collaboration entre enseignants par la théorie enracinée: regard épistémologique et méthodologique," Recherches Qualitative vol. 8, pp. 76-105.

[13] Freeman R. (1994), "The politics of stakeholder theory: some future directions,” Business Ethics Quarterly pp. 409-422.

[14] Fama E. and Jensens M. (1983), "Separation of ownership and control," Journal of Law and Economics, vol. 26, p. 301-326.

[15] Freeman R. (1984), Strategic management: a stakeholder approach, pitman publishing inc.

[16] Friedman M. (1970), "The social responsibility of business is to increase profits," The New York Times Magazine, 13 september.

[17] Gond, J. P. and Igalens, J. (2008), La responsabilité sociale de l'entreprise. Paris: presses universitaires de France.

[18] Huberman A. and Miles, M. (1991), Analyse des données qualitatives - recueil de nouvelles méthodes. Bruxelles: de Boeck University. 
[19] Jensen M. C. and Meckling W. H. (1976), "Theory of the firm: managerial behavior, agency Costs and ownership structure," Journal of Financial Economics, vol. 3, pp. 305-360.

[20] Kaufmann J. C. (1996), L’entretien compréhensif, Editions Nathan, université, (nouvelle édition 2001), collection sociologie, paris.

[21] Lamarque E. (2003), Gestion bancaire, pearson education, Collection: gestion appliquée, $220 \mathrm{pp}$.

[22] Levine R. (2004) "The corporate governance of banks: a concise discussion of concepts and evidence," World Bank policy research working paper.

[23] Macey J. R. and O'Hara M. (2003), "The corporate governance of banks," Economic Policy Review, vol. 9, pp. 91-107.

[24] Maignan I. and Ralston D. (2002), "Corporate social responsibility in europe and the u.s.: insights from businesses' self-presentations," Journal of International Business Studies, pp. 497-514.

[25] Mercier S. (1999), L'éthique dans les entreprises, Editions la découverte, repères, paris.

[26] Mitchell A. B. and Wood D. (1997), "Toward a theory of stakeholder identification and salience: defining the principle of who and what really counts," Academy of Management Review, vol. 22, pp. 853-886.

[27] Orlitzky M. (2001), "Does firm size confound the relationship between corporate social performance and firm financial performance?" Journal of Business Ethics, vol. 33, pp. $167-180$.

[28] Pesqueux Y. (2007), "Ethique et gouvernance: la dualité hard law/soft law," Revue Française de Gouvernance d'entreprise, vol. 1, pp. 35-48.

[29] Porter M. E. (1985), Competitive advantage: creating and sustaining superior performance, New York, the free press.

[30] Prowse S. (1997), "Corporate control in commercial banks," Journal of Financial Research, vol. 20, pp. 1121-1141.

[31] Stiglitz j. and Weiss A. (1981), "Credit rationing in markets with imperfect information," The American Economic Review, vol. 71, pp. 93-410.

[32] Thiétart R. A. (2003), Méthodes de recherche en management, 2éme édition, Editions Dunod, Paris.

[33] Vial V. and Prevot F. (2013), "Effet de la corruption sur la survie des filiales de multinationales dans un pays émergent: cas de l'indonésie," Management International, vol. 18 pp. 58-72.

[34] Vuerings R. (1964), "Problème de gestion d'entreprise en pays sous-développés: la reconversion de l'entreprise privée en Afrique noire indépendante," Management International, vol. 4, pp. 93-104.

[35] Williamson O. E. (1985), The economic institutions of capitalism, the free press, $486 \mathrm{p}$. 